\section{International Criminal Court (ICC)}

Origin. As far back as 1946 an international congress called for the adoption of an international criminal code prohibiting crimes against humanity and the prompt establishment of an international criminal court, but for more than 40 years little progress was made. In 1989 the end of the Cold War brought a dramatic increase in the number of UN peacekeeping operations and a world where the idea of establishing an International Criminal Court became more viable. The United Nations Conference of Plenipotentiaries on the Establishment of an International Criminal Court took place from 15 June-17 July 1998 in Rome, Italy.

Aims and Activities. The International Criminal Court is a permanent court for trying individuals who have been accused of committing genocide, war crimes and crimes against humanity, and is thus a successor to the ad hoc tribunals set up by the UN Security Council to try those responsible for atrocities in the former Yugoslavia and Rwanda. Ratification by 60 countries was required to bring the statute into effect. The court began operations on 1 July 2002 with 139 signatories and after ratification by 76 countries. By Feb. 2009 the number of ratifications had increased to 108. Its first trial, with Thomas Lubanga facing war crimes charges for his role in the Democratic Republic of the Congo's civil war, opened on 26 Jan. 2009.

Judges. The International Criminal Court's first 18 judges were elected in Feb. 2003, with six serving for three years, six for six years and six for nine years. Every three years six new judges will be elected. At present the 18 judges, with the year in which their term of office is scheduled to end, are: Joyce Aluoch (Kenya, 2018); Bruno Cotte (France, 2012); Fatoumata Dembele Diarra (Mali, 2012); Sir Adrian Fulford (United Kingdom, 2012); HansPeter Kaul (Germany, 2015); Erkki Kourula (Finland, 2015); Akua Kuenyehia (Ghana, 2015); Sanji Mmasenono Monageng (Botswana, 2018); Daniel David Ntanda Nsereko (Uganda, 2012); Elizabeth Odio Benito (Costa Rica, 2012); Fumiko Saiga (Japan, 2018); Song Sang-hyun (South Korea, 2015); Mohamed Shahabuddeen (Guyana, 2018); Sylvia Helena de Figueiredo Steiner (Brazil, 2012); Cuno Tarfusser (Italy, 2018); Ekaterina Trendafilova (Bulgaria, 2015); Anita Ušacka (Latvia, 2015); Christine Van Den Wyngaert (Belgium, 2018). René Blattmann (Bolivia), whose term ended in March 2009, will continue to serve for the duration of the Lubanga trial (see above).

Prosecutor. Luis Moreno-Ocampo (Argentina) was elected the first prosecutor of the Court on 21 April 2003.

Headquarters: Maanweg 174, 2516 AB The Hague,

Netherlands.

Website: http://www.icc-cpi.int

President: Philippe Kirsch (Canada).

\section{Further Reading}

Macedo, Stephen, (ed.) Universal Jurisdiction: National Courts and the Prosecution of Serious Crimes Under International Law. Univ. of 2003

Reydams, Luc, Universal Jurisdiction: International and Municipal Perspectives. 2003

Struett, Michael J., The Politics of Constructing the International Criminal Court: NGOs, Discourse, and Agency. 2008

\section{International Institute for Democracy and Electoral Assistance (IDEA)}

Created in 1995, International IDEA is an intergovernmental organization that promotes sustainable democracy worldwide. Global in membership and independent of specific national interests, IDEA works with both new and long-established democracies. IDEA brings together those who analyse and monitor trends in democracy and those who engage in political reform. Its partners include international, regional and national bodies devoted to democratic principles.

Aims and Activities. IDEA aims to: assist countries in developing and strengthening democratic institutions; offer researchers, policymakers, activists and professionals a forum to discuss democratic principles; blend research and field experience, and develop practical tools to improve democratic processes; promote transparency, accountability and efficiency in managing elections; help local citizens evaluate, monitor and promote democracy. The principal areas of activity include: democracy building and conflict management; electoral processes; political parties, including political equality and participation.

Membership. The International IDEA had 25 full member states and one observer state in Feb. 2009.

Organization. IDEA has regional offices in Armenia, Costa Rica, Ghana, Indonesia, Mexico, Peru and South Africa. In 2005 there were 51 international employees.

Headquarters: Strömsborg, 10334 Stockholm, Sweden.

Website: http://www.idea.int

Secretary-General: Vidar Helgesen (Norway).

\section{International Mobile Satellite Organization (IMSO)}

Founded in 1979 as the International Maritime Satellite Organization (Inmarsat) to establish a satellite system to improve maritime communications for distress and safety and commercial applications. Its competence was subsequently expanded to include aeronautical and land mobile communications. Privatization, which was completed in April 1999, transferred the business to a newly created company and the Organization remains as a regulator to ensure that the company fulfils its public services obligations. The company has taken the Inmarsat name and the Organization uses the acronym IMSO. In Feb. 2009 the Organization had 92 member parties.

Organization. The Assembly of all Parties to the Convention meets every two years.

Headquarters: 99 City Road, London EC1Y 1AX, UK.

IMSO Website: http://www.imso.org

Email: info@imso.org

Inmarsat Website: http://www.inmarsat.com

Director of the Secretariat, IMSO: Esteban Pachá Vicente

(Spain).

Chief Executive, Inmarsat Ltd: Andrew Sukawaty (USA).

\section{International Olympic Committee (IOC)}

Founded in 1894 by French educator Baron Pierre de Coubertin, the International Olympic Committee is an international nongovernmental, non-profit organization whose members act as the IOC's representatives in their respective countries, not as delegates of their countries within the IOC. The Committee's main responsibility is to supervise the organization of the summer and 